\title{
THE EFFECTS OF ALTHESIN ON CEREBRAL BLOOD FLOW AND INTRACRANIAL PRESSURE
}

\author{
R.S. COHEN, M.B., B.S., F.F.A.R.A.C.S., F.R.C.P.(c), R.E. СREiGHTON, M.D., F.R.C.P.(c), \\ H.I.A. NISBET, M.B., CH.B., F.F.A.R.C.S., F.R.C.P.(c), \\ P. MCDonald, M.B., B.S., M.R.C.P.(E), F.F.R., F.R.C.P.(c), AND \\ D.J. STEWARD, M.B., B.S., F.R.C.P.(c) \\ with the technical help of G. VolGyesI AND Lisa Joyal
}

As PART OF A CONTINUING SEARCH for suitable anaesthetic agents for use in neurosurgical and neuroradiological anaesthesia, we have studied the effects of Althesin (Glaxo CT1341) on cerebral blood flow (CBF) and cerebrospinal fluid $(\mathrm{CSF})$ pressure in the dog.

Althesin is a mixture of two steroid compounds, both pregnanediones, dissolved in polyoxyethylated castor oil (Child et al.). ${ }^{1}$ Clinical trials have shown that it rapidly induces anaesthesia adequate for various surgical operations (Campbell et al.). ${ }^{2}$

\section{METHOD}

Seven beagle dogs of $11 \mathrm{~kg}$ average weight were used in the experiment. Anaesthesia was induced with intravenous Althesin in an average dose of 4.8 $\mathrm{mg} / \mathrm{kg}$ and $24 \mathrm{mg}$ increments were given intravenously, as required to maintain surgical anaesthesia. A cuffed tracheal tube was inserted and the dog was ventilated with air by means of a Harvard pump to maintain an arterial $\mathrm{P}_{\mathrm{CO}_{2}}$ of 34 to $37 \mathrm{mmHg}$, which is normal for dogs (Pickerell et al.). ${ }^{3}$ The dog was placed on a heating pad.

Catheters were inserted into the right atrium through the femoral vein and into the aorta through the femoral artery. The vertebral artery was cannulated through the other femoral artery using the Seldinger technique under roentgenographic control. Heart rate, blood pressure and temperature were monitored continuously.

When conditions were stable, 1 millicurie of Xenon ${ }^{133}$ dissolved in $1 \mathrm{ml}$ of saline was injected into the vertebral artery and the catheter was then immediately flushed with $2 \mathrm{ml}$ of saline. The appearance and rate of clearance of the Xenon was recorded by a scintillation probe placed over the intact skull and positioned to exclude the airway from its field. A non-rebreathing circuit was used and the expired gases were vented outside the laboratory.

From the Department of Anaesthesia, The Research Institute, The Hospital for Sick Children, Toronto and the Department of Anaesthesia, The University of Toronto, Toronto, Ontario, Canada.

Paper read by Dr. D.J. Steward at the Fifth World Congress of Anaesthesiology, Kyoto, Japan, September, 1972.

Reprint address: Dr. R.S. Cohen, Department of Anaesthesia, The Hospital for Sick Children, 555 University Ave., Toronto, Ontario, Canada. M5G 1X8. 
The cerebral blood flows were calculated by stochastic analysis of the washout curves (Hoedt-Rasmussen et al., Gray et al.)..$^{\mathbf{4 , 5}}$

Simultaneously with the cerebral blood flow measurements, arterial blood gases and cardiac output were measured. The cerebrospinal fluid pressure was measured through a 19-gauge needle inserted percutaneously into the cisterna magna and connected to a pressure transducer and to a continuous recorder.

\section{RESULTS}

Table I gives the mean value and standard deviation for each measurement.

TABLE I

Effects of Althesin/Air Anaesthesia

(7 Dogs)

\begin{tabular}{lcc}
\hline Measurement & Mean & SD \\
\hline $\mathrm{CBF}, \mathrm{ml} / 100 \mathrm{gm} / \mathrm{min}$ & 37.9 & 7.6 \\
$\mathrm{CSF}$ pressure, cm water & 14.4 & 1.2 \\
$\mathrm{~Pa} \mathrm{CO}, \mathrm{mmHg}$ & 35.7 & 2.9 \\
$\mathrm{~Pa} \mathrm{O}, \mathrm{mmHg}$ & 93.0 & 6.8 \\
$\mathrm{pH}, \mathrm{units}_{\mathrm{Cardiac}}$ output, $\mathrm{L} / \mathrm{min}$ & 7.37 & 0.034 \\
MABP, mmHg & 2.3 & 0.45 \\
Temperature, ${ }^{\circ} \mathrm{C}$ & 120.0 & 10.0 \\
& 38.0 & 0.4 \\
\hline
\end{tabular}

\section{DISCUSSION}

Since 1941 various steroids have been known to be capable of producing anaesthesia (Selye) ${ }^{6}$ In 1955 one of these, hydroxydione, was introduced into clinical practice (Taylor). ${ }^{7}$ We could find no reports of measurements of cerebro-spinal fluid pressure or cerebral blood flow during anaesthesia with hydroxydione. Usually steroid hormones reduce cerebrospinal fluid pressure slightly but the reduction is considerable in the presence of cerebral oedema (Hooshmand et al.). ${ }^{8}$

Cerebrospinal fluid pressure in the awake dog is reported to be 13.5 to $15.0 \mathrm{~cm}$ of water (Verdura)..$^{9}$ The mean value during anaesthesia with Althesin was within this range.

Cerebral blood flow in dogs anaesthetized with pentobarbitone was found to be $38.9 \mathrm{ml} / 100 \mathrm{gm} / \mathrm{min}$ (Gray et al.). ${ }^{5}$ The mean value during anaesthesia with Althesin was comparable to this.

These results indicate that Althesin does not increase cerebral blood flow or raise cerebrospinal fluid pressure and thus further investigation of its use in neurosurgery and neuroradiology is warranted.

\section{SUMMARY}

The effects of Althesin anaesthesia upon cerebral blood flow and cerebrospinal fluid pressure were studied in seven dogs. Althesin caused no increase of cerebral blood flow or elevation of cerebrospinal fluid pressure, suggesting that further 
studies should be carried out on the use of Althesin anaesthesia for neurosurgery and neuroradiology.

\section{RÉSUMÉ}

Les effets de l'anesthésie à l’althésine sur le flot sanguin cérébral et la pression du liquide céphalo-rachidien furent étudiés chez sept chiens. L'althésine n'a pas causé d'élévation du flot sanguin cérébral ou de la pression du liquide céphalorachidien. Ceci suggère que des études plus poussées pourraient être entreprises sur l'usage de l'anesthésie à l'althésine particulièrement pour la neurochirurgie et la neuroradiologie.

\section{ACKNOWLEDGMENT}

We wish to thank Dr. W. Zingg and his staff for the use of the facilities in the Animal Research Laboratories, The Hospital for Sick Children, Toronto.

\section{REFERENCES}

1. Child, K.J., Currie, J.P., et al. The pharmacological properties in animals of CT1341: A new steroid anaesthetic agent. Br. J. Anaesth. 43:2 (1971).

2. Campbeli, D., Forrester, A.C., et al. A preliminary study of CT1341: a steroid anaesthetic agent. Br. J. Anaesth. 43: 14 (1971).

3. Pickrell, J.A., Dubin, S.E., \& ErLiotr, J.C. Normal respiratory parameters of unanaesthetized Beagle dogs. Lab. Anim. Sci. 21: 677 (1971).

4. Hoedt-Rasmussen, K., Sveinsdottir, E., \& Lassen, N.A. Regional cerebral blood flow in man determined by intra-arterial injection of radioactive inert gas. Circ. Res. 18: 237 (1966).

5. Gray, I.G., Mitra, S.K., et al. The effect of methoxyflurane on cerebral blood flow in the dog. Can. Anaesth. Soc. J. 18: 408 (1971).

6. Selye, H. Anaesthetic effect of steroid hormones. Proc. Soc. Exp. Biol. (N.Y.) 46: 116 (1941).

7. TAYlor, N. \& Shearer, W.M. The anaesthetic properties of 21-hydroxypregnanedione sodium hemisuccinate (hydroxydione): a pharmacological and clinical study of 130 cases. Br. J. Anaesth. 28: 67 (1956).

8. Hooshmand, H., Dove, J. et al. Effects of diuretics and steroids on CSF pressure: A comparative study. Arch. Neurol. 21: 499 (1969).

9. Verdura, J., White, R.J., \& Albin, M. Chronic measurements of cerebrospinal-fluid pressure in the dog: A new method and results. J. Neurosurg. 21: 1047 (1964). 